\title{
Pedagogical Conditions for Professional Qualities Formation of the Conductor of the Russian Folk Orchestra
}

\author{
Nina F. Semenova* \\ Khabarovsk State Institute of Culture \\ 112 Krasnorechenskaia Str., Khabarovsk, 680045, Russia
}

Received 21.03.2016, received in revised form 04.04.2016, accepted 18.05.2016

\begin{abstract}
The paper observes the issues connected to professional training of conductors of folk instruments orchestras and music directors of creative groups. The author rightly points to the necessary consistency and unity in such creative aspects as: educational, enlightening, concert, performing, scientific and methodical components in the training of professional musicians. The author showed determinant constituent of the entire spectrum of training levels which include historical, theoretical, performing, ideological levels of pedagogical education. The author expects positive prospects related to the development of preparation of future conductors of the Russian Folk Orchestra.
\end{abstract}

Keywords: orchestra of folk instruments, conducting, music education, pedagogical skills, performing culture, concert and performing activities.

DOI: 10.17516/1997-1370-2016-9-6-1434-1442.

Research area: pedagogy.

Modern pedagogy of music education makes more and more demands on the training of highly qualified conductors specialized in working with the Russian Folk Orchestras.

The modern system of training of a future conductor has a layered and branched structure. The conditions of work and training orchestras, state standards, curricula and educational programs, approaches and principles, forms and methods of training, etc. are of great importance. But ultimately the whole result largely depends on the skill of the music director of the orchestra and the teachers who will carry out the educational activity.

An analysis of studies devoted to the pedagogical skills shows that despite certain differences scholars have identified three relatively distinct but interrelated parts in this structure: personal qualities and abilities, professional knowledge and skills to be in charge of the pedagogical process; excellence in the teaching activities (educational technology, pedagogical tact, teaching experience, knowledge of methodology, etc.).

In the world in general, as well as in the artistic and pedagogical world in particular, a primary origin is a man with his/her personality, qualities and traits, professional and creative status as a music teacher, an organizing teacher, an educating teacher. These skills result in the artistic and educational work. A teacher who lacks

(c) Siberian Federal University. All rights reserved

* Corresponding author E-mail address: semenova_nf@mail.ru 
professional and personal excellence can destroy and ruin any good beginning. A skilled and creative teacher always overcomes the difficulties that contribute to his/her skills and to finds the ways to achieve the main goal, i.e. educating both the musician and personality. Today the folk orchestras have an essential need in erudite, broad-minded, and skilled in educational and performing art teachers.

Even K.D. Ushinsky paid much attention to the personal qualities of the teacher. He pointed out that in the learning process "...everything should be based on the teacher's personality, because the educational power pours only from the living source of the human person... Only a person can influence a person... The character can form another character" (Ushinsky, 1950, p. 171). V.A. Sukhomlinskii wrote on this subject as such: "The spiritually rich, morally bright, intellectually gifted personality is capable of respecting their students and educating them as outstanding people. Impersonality dehumanizes the students, leading to wretchedness" (Suhomlinskii, 1979, p. 79).

Many scholars have identified such personal qualities required for a teacher as fairness, responsibility, sense of duty, reliability, diligence, discipline, self-control and emotional control, kindness, sensitivity, willingness to help, and so on. One of the most important personal qualities of the teacher, making a profound impact on the level and effectiveness of training, the creative development of the orchestra is a strong interest of music director of the orchestra and music teachers.

Such important component of pedagogical skills as a conglomerate of professional knowledge incorporates the teacher's knowledge of the subject, the degree of professional directions, the breadth of scientific interests in the field of the taught discipline, range of outlook, worldview in general, etc. As if projecting this statement in the music area, we can highlight the following necessary components: knowledge of the history of creation of, for example, a musical instrument, its design, construction, forms of development, knowledge of information about the performance capabilities of the instrument, orientation in the repertoire. This knowledge should include knowledge in the field of musical-theoretical disciplines, art history, culture studies and the general pedagogical and musical knowledge. It is important not to forget about the knowledge in the field of teaching methods, instrumentation, arrangement, music writing, conducting and certainly of the orchestra (ensemble) performance, etc.

It should be noted that the personal and professional traits of the music director of the orchestra are strongly intertwined and integrated. As the profession of the teacher-musician in many ways is of enlightening character, especially of the individual personality, the personal teacher's traits can also be included in the category of professional qualities.

Personal qualities are significantly manifested in any activity, as well as in the system of orchestral and ensemble performance in cultural institutions. A.S. Makarenko argued that "... the teaching profession is one of the most creative, since it assumes a constant search for new, unconventional solutions, the rejection of stereotypes, which do not guarantee success with the sensitive and attentive audience" (Makarenko, 1951, p. 125-126). Nearly a century separates us from his time, but the elapsed time has not changed the perception of the teacher's path as truly creative, demanding high commitment, systematic work in self-development, selfeducation.

It should be emphasized that for us the most important part is not to consider different definitions related to teaching art, but to understand the nature of relations between its 


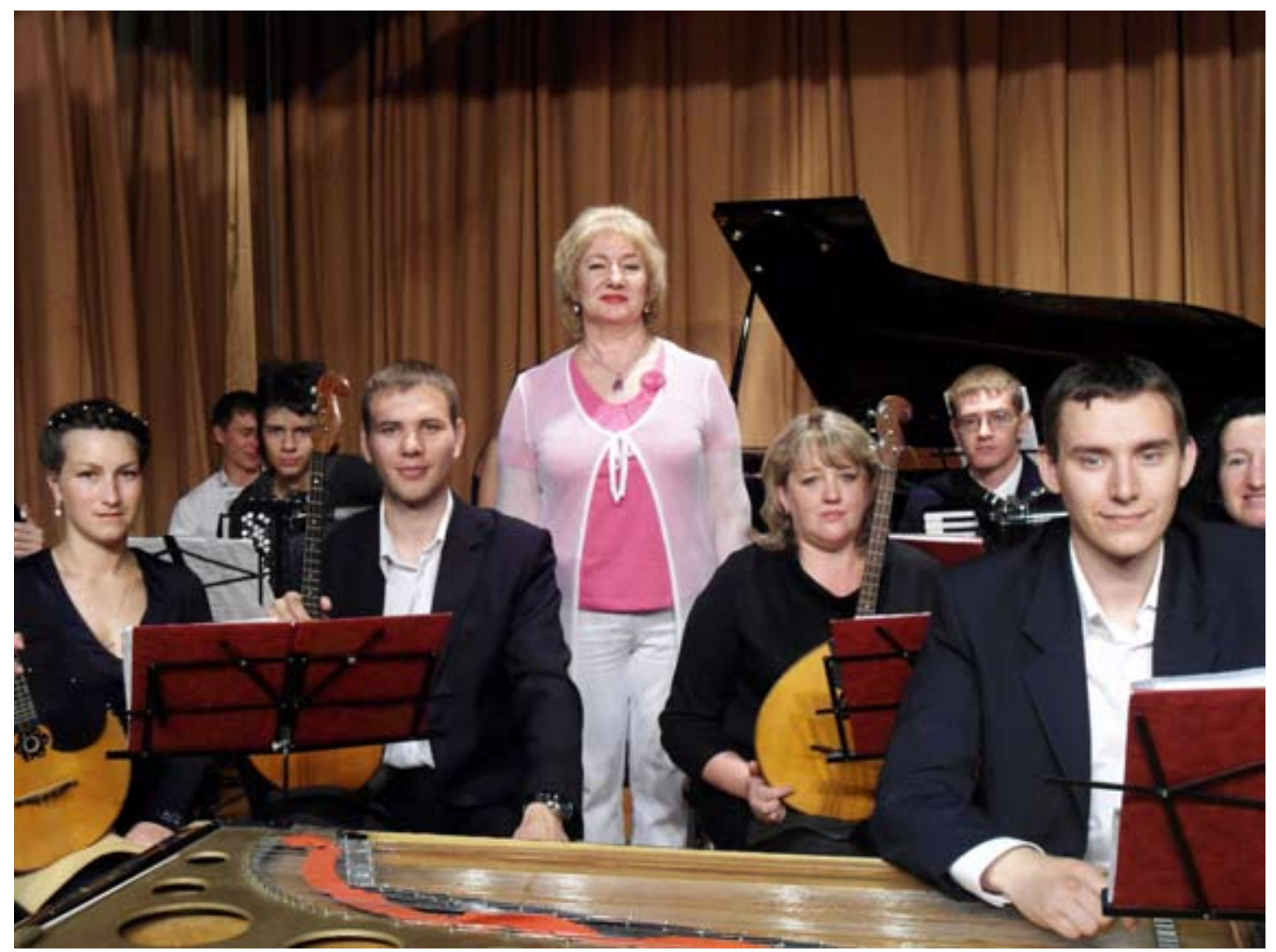

components, identifying the main structural components.

From all variety of abilities and skills of the teacher to enable a pedagogical process, many scholars have identified the following abilities:

- to arrange teaching material in accordance with the curriculum;

- to select the material for lessons given student abilities to perceive it;

- to present the educational material in an interesting, reasoned and convincing way;

- to evaluate the pedagogical situation quickly and correctly;

- to use active forms and methods of teaching, activization methods of cognitive activity of students;

- to evaluation the degree of students' knowledge of the educational material;

- to demonstrate self-critical attitude towards their work;
- to apply individual approach to education;

- to enlighten students and implement other educational tasks.

It is needless to say that in pedagogy and psychology there is neither well-founded system of teacher skills' formation, nor unity of opinions in the interpretation of the teacher skills' essence.

To date, the theory of art and pedagogical education can demonstrate three most clearly developed classifications of pedagogical skills: 1) according to the functions of formulating and solving pedagogical tasks of various levels (I.T. Ogorodnikov, N.V. Dmitriev, A.F. Spirin, etc.); 2) according to the pedagogical function of the teacher and educator (N.V. Kuz'mina, L.N. Shcherbakov, O.A. Abdulina, etc.); 3) according to the management of the educational and training process (V.A. Slastenin, etc.).

In recent years the researchers have increasingly expressed opinions about 
“... the feasibility of differentiation of the most common, so-called integrated or 'pervasive' skills that are an essential component of the teacher's work in any specialty in organizing any kind of educational activities and mastering individual skills. The fact is that an attempt to circumvent the general skills always turns out to be unsuccessful, while the list of mandatory individual skills counts up to several tens or even hundreds skills" (Mishchenko, 1997, p. 120). The study of the nature and structure of pedagogical activity provides clear understanding of the general nature of certain skills that are used in a wide range of specific educational objectives. Such general pedagogical skills should include the ability to think and act pedagogically. These skills are inextricably linked with the ability to observe and analyze the pedagogical facts, in other words, to carry out a complex process of transition from the concrete to the abstract level. This transition may occur on an intuitive, empirical and theoretical levels, bringing skills to the theoretical mastering, where the expertise will be required. The theoretical level is one of the essential aspects of teaching the students pedagogical skills.

The complete cycle of reaching the pedagogical objectives can be represented by the formula "think - act - think".

In his study V.A. Slastenin distinguishes five levels of professional and pedagogical skills:

1. Intuitive level. In this case, students (pupils) carry out the solution of pedagogical problems in the subconscious (unconscious) level, relying fully on intuition. In most cases they cannot explain the reason for the choice of certain ways, forms and methods of action, the appropriateness of their use.

2. Reproductive level. At this level, students use the patterns, stereotypes, traditional forms and methods of teaching. Their credo is strict adherence to rules, regulations, and established standards.

3. Reproductive and creative level. It is a kind of the starting point of the way associated with the development of pedagogical creativity of students. They are quite confident in standard situations, but have difficulties getting in the extraordinary situation. The creative solution comes with effort and not immediately.

4. Creative and reproductive level. A distinctive feature of this level is that students have the pedagogical knowledge, have abilities and skills, on the basis of which they successfully carry out the solution of educational tasks. At the same time creative approaches, forecasting, enabling dynamic pedagogical process, have not yet received a proper application.

5. Creative level. At this level, students are able to articulate and support their teaching position, possess professional skills, in particular, the theoretical and analytical, prognostic, structural, organizational ones and others. Students show interest in and desire for creative use of their knowledge and skills, using the latest teaching technologies (Slastenin, 1977, p. 150).

This "layer" approach makes it possible not only to trace the dynamics of formation of bases of pedagogical skills of studying orchestra musicians, but also to understand the essential content that determines the professional and creative status of the teaching musician. It consists of personal qualities, professional knowledge and skills at a special and an "integral" (generalized) level, plus the ability to use creatively the entire available teaching arsenal of pedagogical means.

In high schools of arts and culture, teachers should recognise all areas of his creative work, which will largely determine the choice and application of forms and methods of activity. The ability to identify specifically on an individual basis possible ways of creative development of the students, to create conditions for their 
multifaceted growth, expanding horizons as a whole is the important strategic objective for each level of both the educational and musicaleducational system. It is necessary to proportion the volumes of the teaching material, to monitor the interdependence of the pedagogical processes.

Many teachers at art and culture universities, including music ones, pay attention to the improvement of their special professional knowledge and skills, but sometimes forget about the scientific-methodical, research, work, about the search for active forms, teaching approaches and methods, etc. Minimization of these types of creative work, and sometimes their complete disregard lead to negative consequences in the pedagogical practice. Teaching and research work are based on an analysis of facts and involve foresight, so they are close to each other; the teacher must be a thinker, to penetrate into the depth of what is happening, to comprehend the cause-and-effect relationships.

Currently, an important active aspect of modern educational institutions of culture, cultural and recreational centres is the search and research work. All the more urgent is the problem of training future specialists with high professional and artistic status. The most prominent components are pedagogical creative work and thorough scientific-pedagogical thinking. Creativity and ability to be a thinker are valuable indicators of competence and professionalism of the teaching musician.

Specificity of musical and pedagogical activity lies in three-pronged manifestation of creativity: pedagogical creativity; work related to the impact on the orchestra musician's personality through the art; scientific work, allowing the musician to analyze the results, to summarize positive experience, to stimulate the further development of musicians. Training, educational, concert, performing, scientific and methodical work on the basis of creativity is the basis of pedagogical skill of the conductor and music director of the orchestra. Nothing can be eliminated. Scientific work is no substitute for performance, but performance may not reflect the teaching skills. Each activity in itself is meaningful, and the success of the creative process lies only in this trinity.

Why should be this trinity of directions? Many laymen may ask such a question. And indeed, there is a large number of teachersmusicians who, at first glance, are engaged in the same line, and, nevertheless, achieve excellent results. For example, a number of teachers in universities and colleges of arts consider the dominant focus of their work the intensification of performing activity of students. They are aimed at training the winners of national and international competitions (results of the express survey on the territory of the Far Eastern region). But this is only the outer side of the coin. Some people, taking these results as a model in its pure form, imitating them, practice only performance in the narrow sense of the word, come to deplorable results. What is the reason for this?

In fact, the increase in performance culture of the orchestra musicians is a vital component of their training. Improving the performance skills is a not a unilateral process, as it has a deterministic and indirect character. But as the process of comprehension of performance culture vertices is not isolated, let us turn to some moments of determination and cooperation in this direction of musical activity.

It is axiomatic that performance embraces the proficiency in techniques and insights into musical and image content, bringing it to the spectators (listeners). Some teachers are focused mainly on the technical capabilities of students. In this approach, the musical and image content can be emasculated by the technical aspect of the process. There is the opposite method, 
which orients on the comprehension of secrets of a musical work, but it does not particularly take into account the importance of the ways of its realization technology. Both the first and the second trend in the musical performance lead students to one-sided, limited development, negating the essential content of the performing art, which is essentially polyphonic, having a layered structure. The result of these actions, as a rule, is only one - the lack of performance, conservatism, pettiness. Understanding the performing art as a holistic, multi-dimensional process is the key to the successful implementation of this type of creative activity, which organically combines both technical and musical (image) culture of behavior on the scene, and other aspects of the stage reproduction.

Development of the internal structure of the performance culture provides a wide range of cooperation on cross curricular level of musicaleducational system. The need to obtain deep musical and theoretical knowledge (in subjects of the general music cycle, such as "History of Music", "Solfeggio", "Analysis of Musical forms", "Harmony", "Polyphony", etc.) for the successful development of playing can be compared with the human need for oxygen without which life is simply impossible, and without which all other earthly problems automatically disappear, become meaningless. However, it should be emphasized that knowledge of musical disciplines does not provide a sufficient basis for the full development of the performing musician. Informal study of the subjects of the general education cycle may expand cultural basis and the horizons of the enrolled students.

One cannot but note that behind the glare of the winners of medals there is not only a great and laborious work of teachers and students. As a rule, the teacher, whose mentees achieve these results, is the winner him/herself and has acquired the most difficult performing skills, and has a considerable experience of live performances, which can be shared with the students. Therefore the teacher has a deserved authority and trust among the students. Such work demands at the same time a great teaching art. On the one hand, it is a chief part to choose the means and forms of pedagogical influence, through which you can convey to the student the idea of the arcane meaning of the musical image; on the other hand, the teacher should teach the student to embody the figurative content using the musical palette of the instrument. Music director of the team of performers should analyze the course of study, summarize all the positive and negative aspects, take into account the individuality of the orchestra musician, constantly develop the students both spiritually and creatively, and "clear" the students' road to mastery to improve their holistic personality. Thus, there is a vivid three-pronged manifestation of creativity: the educational and enlightening constituent, the concert and performing work, and the scientific and methodical approaches.

It should be understood that such an approach is not an end in itself, embodying whateverism, but a means to reach an end, which in many ways is to increase the professional level of creativity for a conductor, a teaching musician and an orchestra musician.

The analysis of current reality shows that art education, together with the strategic and tactical approaches in the educational process, may be a priority in one or another form of musical and pedagogical creativity (whether it is a concert, performing, scientific or methodological activity, etc.). In turn, the requirement is that the teacher should not restrict the work by one direction, rather the teachers should strive for the gradual equalization of educational activities in all three aforementioned directions. The solution of this problem will help to expand the sphere of competence, to expand the horizons, to contribute 
to the rise of professional and creative status of a conductor and a teaching musician in general.

For the scientific analysis purpose we subjected artistic and pedagogical process to differentiation and distinguished three areas: teaching and educational one, concert and performing work, and scientific and methodical approach, which correspond to a certain threepronged creative foundation. Three angles are made up of pedagogical creativity, creativity directly associated with the performing arts, and scientific creativity.

In the musical and educational practice all the components of the structure are interconnected and interdependent; they make an inseparable unity, feeding each other with new creative content. We can conclude that by leaving out of the account at least one of the three life-giving sources conducing to work, we would greatly impoverish artistic and pedagogical work, narrowing the range of creative and self-development possibilities of the teacher and the student. Limitations of the educational process within certain limits, keeping it in a single-tone mode, are contrary to the very principle of creativity and artistic freedom. These limitations would eviscerate the essential content of the activity and the creative nature of the musician. Triune integrity of artistic and pedagogical process allows one to create a fully meaningful creative environment, which can boast good opportunities both for finding new forms and methods of work, means of expressions, and for reflecting every new idea in the scientific, methodological, repertoire and pedagogical material. The ability to carry out many-sided musical and educational work successfully determines to a large extent the professional and creative status of any conductor and a teaching musician in general.

Today, the music director of the orchestra does not only need to be involved in constant self- development, but also to improve their knowledge and skills, to try to open creative reserves inside and realize them. Professional and creative mastery of the conductor, unfortunately, has certain limits. $\mathrm{He} / \mathrm{she}$ also like a fruit on a tree can be "spoiled" in course of time, become obsolete, fail in meeting the modern musical and artistic interests of musicians. It is imperative to continually keep pace with the times, educating future musicians on the creative basis, regularly giving momentum to performing orchestra musicians to foster their creative selfdevelopment.

I.A. Musin quite reasonably stressed that “... for the success of rehearsal work young conductors require special knowledge and in particular the development of attention. The knowledge is acquired from different sources from teachers, from books, from their own observations. Concentration is developed by a special purposeful work. The knowledge and attention, as though having a different nature, are closely linked. So attention is a fundamental principle of knowledge, which is based on the experience of previous activities. Focused attention is always straightforward, as it has a specific purpose. In turn, focused attention enriches and expands our knowledge" (Musin, 2011, p. 168). This statement confirms the close relationship of knowledge (scientific and theoretical basis), skills (training and educational basis) and performing experience (concert and performance practice).

Students are attracted by the professionalism, uniqueness and individuality of their teachers. In exchange, they almost always notice all the shortcomings of the teacher, responding to his/her mistakes, feel their mood fine, etc. Therefore, the teaching musician, by and large, has no right for error. The modern teacher must be a performer, a teacher and a lecturer, and a scientist.

What is the best way of self-development work for the teachers themselves? How to 
combine the seemingly incompatible things analytical thinking and creative impulse, deep analysis and spirituality of virtuoso performance, etc.? But it is this diversity of musical and creative activity of the music teacher, which enables systematic and rapid moving towards professional development.

As practice shows, the harmony is the unity of different things. Systematically and consistently developing musical abilities the teacher creates a good basis for raising the level of mastery.

In turn, the performance (the very creativity) can nourish the pedagogical art and become the basis for the so-called primary creative activity. In this regard, the indicative work is the author's one, which may be represented in the form of, for example, composing, writing transcriptions, instrumentation, adaptation, as well as writing training programs or guidelines.

Everything said about the performance art reveals and emphasizes the need for cooperation of the historical, theoretical, actual performing and ideological levels in musical creativity. The quality of such a deterministic approach depends on purposeful and reasonable combination of the actual teaching, concert and performing work and scientific approach on the foundation of creativity.

Based on the foregoing statement, we shall conclude that under current conditions it is very important to bring up a creative thinking person; it is necessary to form the performing culture of the orchestra musicians, which is so indispensable in the pedagogy of professional music education.

\section{References}

Makarenko, A.S. (1951). Polnoe sobranie sochinenii: v 6 tomah [Full collection of works: in 6 vols]. Moscow: APN RSFSR.

Mishchenko, L.I. (1997). Teoreticheskie osnovy formirovaniia soderzhaniia pedagogicheskogo obrazovaniia [Theoretical foundations of forming the content of the pedagogical education]. Dis. ... doktora pedagogicheskikh nauk: 13.00.01. [Dissertation for Doctor of Pedagogical Sciences]. Kursk, $420 \mathrm{p}$.

Musin, I.A. (2011). Iazyk dirizherskogo zhesta [The language of the conductor gesture]. Moscow, Muzyka, $232 \mathrm{p}$.

Slastenin, V.A. (1977). Formirovanie lichnosti uchitelia v processe ego professional'noi podgotovki [Formation of the teacher's personality in the process of the professional training]. Dis. ... doktora pedagogicheskih nauk: 13.00.01. [Dissertation for Doctor of Pedagogical Sciences]. Moscow, 386 p.

Suhomlinskii, V.A. (1979). Izbrannye pedagogicheskie sochineniia [Selected pedagogical works], 1. Kiev, $558 \mathrm{p}$.

Ushinsky, K.D. (1950). Sobranie sochinenii: v 3 tomakh [Collection of works: in 3 vols], 1. Moscow. 


\section{Педагогические условия формирования \\ профессиональных качеств дирижера \\ русского народного оркестра}

Н.Ф. Семенова

Хабаровский государственный институт культуры Россия, 680045, Хабаровск, ул. Краснореченская, 112

В статье раскрываются вопросы, посвященные профессиональной подготовке дирижеров оркестров народных инструментов, музыкальных руководителей творческих коллективов. Автор справедливо указывает на системность и единство в проявлении творческого начала таких аспектов, как учебно-воспитательный, концертно-исполнительский и научно-методический в подготовке профессиональных музыкантов. Отражена детерминантность всего спектра уровней подготовки специалистов, которая включает в себя исторический, теоретический, исполнительский, мировоззренческий уровни педагогчческого образования. Положительным моментом является видение автора, связанное с перспективами развития подготовки дирижеров русского народного оркестра.

Ключевые слова: оркестр народных инструментов, дирижирование, музыкальное образование, педагогическое мастерство, исполнительская культура, концертно-исполнительская деятельность.

Научная специальность: 13.00.00 - педагогические науки. 